Journal

of Geography

Politics and Society

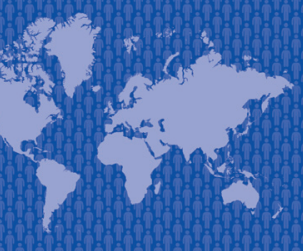

$8(1) / 2018$

\section{Journal of Geography, Politics and Society}

$2018,8(1), 64-70$

DOI 10.4467/24512249JG.18.008.8160

\title{
UKRAINIAN PRACTICE OF THE MILITARY RADIO BROADCASTING DEVELOPMENT DURING THE MILITARY CONFLICT
}

\author{
Tetiana Hyrina \\ Advertisement, Journalism and Social Communications Department, Classic Private University, Zhukovsky 70B, 69000 Zaporizhzhya, Ukraine, \\ e-mail: hirinatetyana@gmail.com
}

\section{Citation}

Hyrina T., 2018, Ukrainian practice of the military radio broadcasting development during the military conflict, Journal of Geography, Politics and Society, 8(1), 64-70.

\begin{abstract}
The article explored the potential of radio broadcasting in a coverage of the military conflict in Ukraine. It is determined that the most specific for Ukrainian broadcast is an entertaining, social and psychological, arts and cultural, patriotic (ideological and agitational), historical, information and analytics projects, demonstrating that the potentiality of radio broadcasting make such radio programmes closer to the broadcast listener not only at home, but and in the trenches or in the adaptation after the combat area service. The author notes the lack of attention of radio companies to the topics of anti-terrorist operation (ATO), and focuses on the potential of radio broadcasting for the social adaptation of service members and people affected by military conflict in eastern Ukraine and Crimea in the postwar period.
\end{abstract}

\section{Key words}

military conflict in Ukraine, social adaptation, type of radio programme, Ukrainian radio broadcasting.

\section{Introduction}

Today Ukrainian information space torn by invasive enemy hands is a concern in various aspects both within the country and abroad. This is largely related to the sluggish response of the media to the challenges posed by the conjuncture of external and internal media space, which is transforming daily. Under the influence of enemy attacks both at the contact level and in a plane of virtual fight a new segment of media hardened by enemy attacks on freedom of the spirit and will of Ukrainian people is forming in Ukraine. In this conditions today every media channel carries out own information fight and has small victories in the war of semantic contradictions, by which the enemy litters the civils thoughts.

Usually entertaining, easy to perceive, energetic and exciting radio broadcast in conditions of the military conflict faced a difficult dilemma. The management of every radio station looked for an own unique compromise between the own traditional positive nature and deeply offended spirit of public conscience. As a result, some have decided to shift the traditional focus in the radio broadcast to accommodate challenges of modern times, while others began to ignore topics that are contrary 
to the editorial concept of carelessness of radio broadcast. However, the closer a radio station is to the demarcation zone, the harder it is getting to avoid topics that sound polyphonically from the window of every car, home or office. In a situation of permanent stress a radio set can become just so a safety valve, so a source of latest information, medium of communication and exchange of ideas.

Special aspects of performing by journalists their duties in conditions of military conflict are described in the works of Ukrainian and foreign researchers of mass media. Among these are works of M.E. Garcia Raya (2003), D. Reljiic (2004). Results of Ukrainian scientists' explorations devoted to this topic regularly appear. These include works of H. Rodyk (Родик, 2012), O. Pashnina (Пашніна, 2009), H. Kobra (Кобра, 2009), M. Kondratiuk (Кондратюк, 2013), L. Putkalets (Путькалець, 2015) and others. Vitally valuable for Ukrainian journalists working in conditions of military conflict are recommendations developed by a group of scholars, including $\mathrm{M}$. Buromenskyi (Буроменський, 2016). However, the potential of radio broadcasting both in the process of chronicle coverage of military events and as an entertaining, social and adaptive media channel has not yet been conceptualized in complex on a scientific level.

\section{Research results analysis}

In the Ukrainian radio broadcast the programs devoted to the subject of ATO are reflected in entertainment, social and psychological, arts and cultural, patriotic (ideological and agitational), historical, information and analytics projects.
According to the results of the monitoring study we identified and analyzed 47 specialized radio programmes on military topics on the broadcasting of 246 studied Ukrainian radio stations ${ }^{1}$ (Fig. 1) (Гиріна, 2016).

The important specifics of such programmes is their acute compliance with the challenges of the times, so they have not only an entertainment function, a traditional one for them, but also an approach of interests'function. In fact, central figures of the programmes - yesterday's neighbors, brothers, children and husbands of Ukraine people from everywhere today send greetings from the trenches, speak about their health condition, report from rehabilitation centers, and volunteers coordinate the directions of further cooperation. Thus, on the other hand, a small number (at first glance) of specialized radio projects on ATO topics can be seen as an effective ground for development. And vitally important and telling is the fact that the state does not remain on the sidelines of such processes supporting the projects financially. The conducted monitoring of Ukrainian radio stations showed the following division of radio programmes on the military conflict topics (Fig. 2) (Гиріна, 2016).

Unfortunately, despite the numerical superiority of private radio companies over the state ones, the figure enabled to document an inversely proportional level of attention to radio programmes on ATO topics. While the broadcasting of almost every regional branch or the National Radio Company of Ukraine presents certain projects, revealing the situation in eastern Ukraine and Crimea, for the majority of nonstate radio stations an issue of coverage the military conflict within special radio projects does not exist.

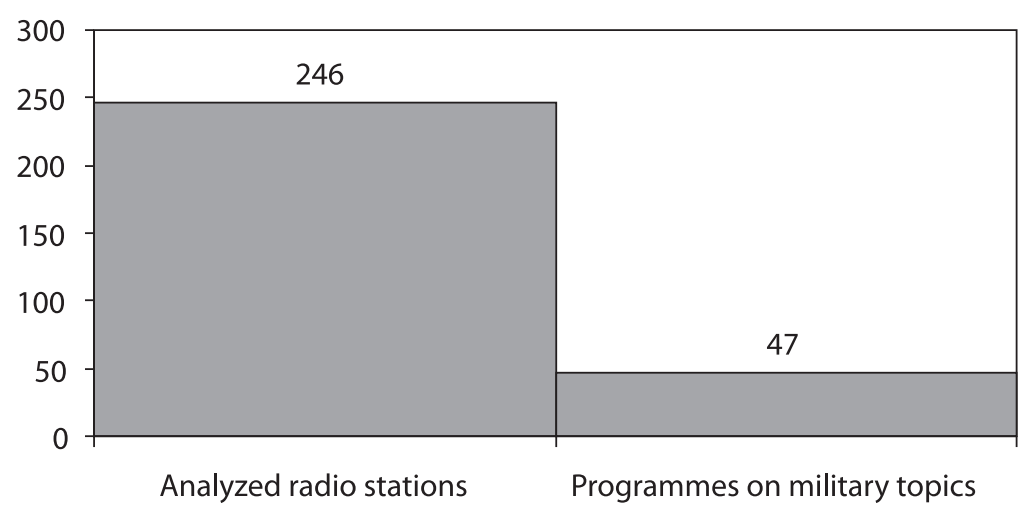

Fig. 1. Quantitative characteristics of the presence of radio programmes of military topics in the broadcasting of Ukrainian radio stations (November, 2016)

Source: Own studies.

\footnotetext{
1 Including 29 satellite radio stations, 5 Internet radio stations, 9 Ukrainian-speaking radio stations of the world and 203 regional radio stations in november, 2016.
} 


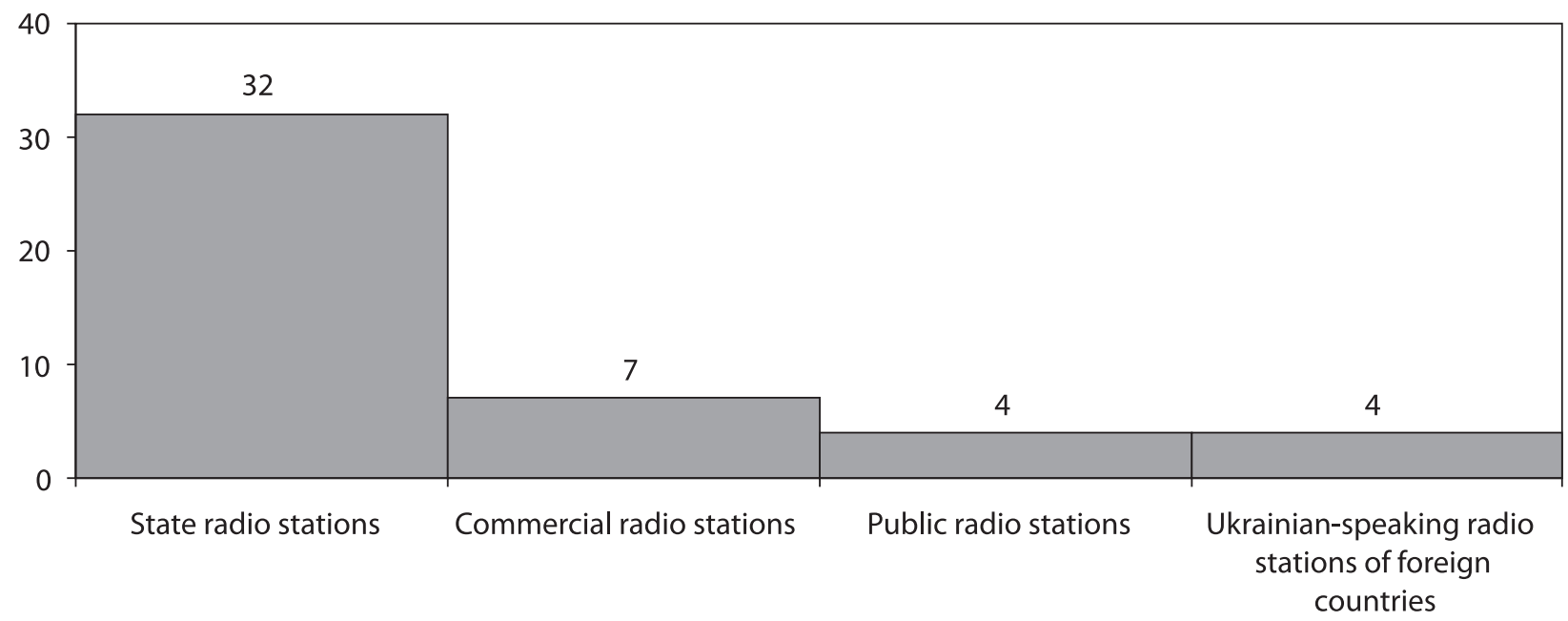

Fig. 2. Presentation of radio programmes on the ATO topics in the broadcasting of radio stations of different forms of ownership (November, 2016)

Source: Own studies.

Instead, we note a systematic address to events in the area of military conflict in the news releases, programmes of greetings and congratulations, dialogue of DJs, the music content. Here a pleasant exception is the broadcast schedule of the "Epa FM" (Era FM) radio, where during the week at once several programmes, devoted to analyzed problems, are introduced to the listeners, and some episodes of other programmes also refer to the theme of military conflict. But in this case we also have to remember that this radio station is a talk one, while the most part of stations in the Ukrainian radio space is the music and entertainment ones, so they do not dare to emphasize the militaristic topic in their broadcasting. Ukrainian-speaking editorial staff of foreign radio stations also talk about the war within the territory of Ukraine, but they mostly do it not in specific programmes, but within thematic rubrics. We connect such a trend with the geographic remoteness from the conflict zone and complexity of obtaining unique information by journalists.

The opposite trend consolidates in the public broadcasting sector. For example, for the broadcast on the "Громадське радіо" (Hromadske radio; Public Radio) journalists are preparing four appropriate radio programmes. With the financial support of the state the Donetsk Regional Directorate of Public TV and Radio Company of Ukraine, which is represented by the "Голос Донбасу" (Holos Donbasu; Voice of Donbas) radio station, resumed the broadcasting. By early 2017 four radio companies got a license from the National Council on Television and Radio Broadcasting of Ukraine to broadcast in the occupied Crimea.

So across the peninsula the "Українське Радіо" (Ukrainske Radio; Ukrainian Radio) (100.7 FM) and
"Meydan Radiosı" (101.4 and 90.8 FM) can already be heard. The start of broadcasting of the "Радіо Крим Реалії" (Radio Krym Realii; Radio Crimea Realia) and the "Херсон FM" (Kherson FM) is scheduled (На окупований Крим почали мовлення..., 2017).

But a special part in the national information space plays the comprehensive Ukrainian state military "Армія FM" (Armiia FM; Army FM) radio station, which broadcasts under the slogan of "To inform, to hear, to support." It is unique not only because it was established to inform about the activities of Ukrainian military, but also because it is the first radio station of the Ministry of Defense of Ukraine created since 1992. In this respect more than for two decades a unique one was the "Бриз" (Bryz; Breeze) TV and radio company, which after the annexation of Crimea was moved to Odesa and transformed into a TV studio. And the newly established at March 1, 2016 "Армія FM" radio station now has become not only an information platform for the military, but next to the one unprejudiced Ukrainian-speaking source for obtaining of information from Ukraine in settlements front-line to the demarcation zone. Although the radio station is the state-owned, the financial support of the foreign charitable organization "Spirit of America" (USA) was involved to its creation (США проспонсируют создание B Украине военного радио, 2015).

In an interview in celebration of the first anniversary of the station, its founder and leader, Lieutenant Colonel of the Armed Forces of Ukraine Ya. Kholodna noted that "The "Армія FM" is one of the few examples of successful state projects in the information sphere. The radio, created by the military and for the military, it would seem, was doomed to be a sort of audio version of army regulations, however, 
quality music and creative work of radio station's staff made almost impossible - today the military radio wave is gaining more and more supporters, and not only among the service members, but including civilians of ATO zone" (ЛаптєВ, 2017). In addition to the broadcasting in the World Wide Web in the format of the audio stream on the "Svoeradio" (Svoie Radio; Own Radio) portal (Військове радіо "АРМІя FM" на "Svoeradio", 2016, 2016), today the radio station can be heard in the FM gamut in Kramatorsk (105.3 FM), Bakhmut (105.3 FM), Kostiantynivka (105.3 FM), Pokrovske (105.3 FM), Mariupol (89.5 FM), Volnovakha (87.6 FM), Hirnyk (87.8 FM), Ocheretyne (89.1 FM), Sloviansk (88.9 FM), Novoaidar (91.6 FM), Shchastia (98.5 FM), Luhanska Cossack village (90.8 FM), Novotoshkivka (90.8 FM), Krasnohorivka (105.3
FM), Svitlodarsk (107.4 FM), Hranitne (98.5 FM) and Shyrokyne (95. FM) (Військове радіо "АРМІЯ FM" на "Facebook", 2016). The management declares that "the radio is heard almost throughout the ATO zone - we cover $70 \%$, and maybe more, given the fact that our radio waves reach the temporarily occupied territories of Ukraine" (Військове радіо "АРМІЯ FM" на “Facebook", 2016).

Thus from the project addressed only to military, the radio turns into a source for the obtaining of reliable information about events in the country, that takes a particular significance in the conditions of information vacuum in which people live in those areas.

Despite the seemingly predictable political and ideological influence of the Ministry of Defense of

Tab. 1. Broadcast schedule of "Армія ФМ" radio station (April 2016)

\begin{tabular}{|c|c|c|c|}
\hline No & Broadcast title & Day and time of going on the air & Presenter \\
\hline 1. & “Рота, підйом!” (Rota, pidiom! Troop, Wakey!) & $\begin{array}{l}\text { Mon, 7:00-11:00 } \\
\text { Tue-Fri 7:00-10:00 }\end{array}$ & P. Boiko \\
\hline 2. & $\begin{array}{l}\text { “Правовий інструктаж” (Pravovyi instruktazh; Juristic Instruc- } \\
\text { tion) }\end{array}$ & $\begin{array}{l}\text { Mon-Fri, 10:30-10:35 } \\
\text { Mon-Fri, 15:30-15:35 }\end{array}$ & M. Markevych \\
\hline 3. & "Неформат" (Neformat; Non-Format) & $\begin{array}{l}\text { Mon, Wed-Fri, 13:30-13:40 } \\
\text { Tue, 13:30-13:40 }\end{array}$ & I. Kravchenko \\
\hline 4. & “Привіт в ATO” (Pryvit v ATO; Hello to ATO) & Mon, Wed-Fri, 14:00-15:00 & \\
\hline 5. & "Уроки англійської” (Uroky anhliiskoi; English Lessons) & $\begin{array}{l}\text { Mon, Wed-Fri 12:30-12:35 } \\
\text { Mon, 16:30-16:35 }\end{array}$ & \\
\hline 6. & "Ветерано бізнес" (Veterano biznes; Veteran Business) & Mon, 17:00-18:00 & L. Ostaltsev \\
\hline 7. & "Тепер ти в армії" (Teper ty v armii; You in the Army Now) & $\begin{array}{l}\text { Mon, } 20: 30-20: 35 \\
\text { Sat, } 15: 30-15: 35\end{array}$ & D. Ishchenko \\
\hline 8. & “Під сумнівом” (Pid sumnivom; In Ambiguo) & Tue, 9:30-9:40 & A. Bulharov \\
\hline 9. & $\begin{array}{l}\text { "Алло! Ми шукаємо Штірліца!" (Allo! My shukaiemo Shtirlitsa! } \\
\text { Hallo! We Are Looking for Stierlitz!) }\end{array}$ & $\begin{array}{l}\text { Tue, } 12: 30-12: 35 \\
\text { Tue, Thu, 16:30-16:35 }\end{array}$ & A. Krachenko \\
\hline 10. & “Незламна” (Nezlamna; (She Is) Adamant) & Tue, 14:00-15:00 & M. Markevych) \\
\hline 11. & “Сектор Л” (Sektor L; Sector L) & Tue, 17:00-18:00 & $\begin{array}{l}\text { K. Potapenko, } \\
\text { M. Muzyka }\end{array}$ \\
\hline 12. & “МінБрест” (MinBrest) & Tue, 19:00-21:00 & M. Brest \\
\hline 13. & “Спецоперації” (Spetsoperatsii; Special Ops) & $\begin{array}{l}\text { Tue, Wed, 20:30-20:35 } \\
\text { НД 20.30-20.35 }\end{array}$ & V. Shvachkin \\
\hline 14. & "ЗброяUA" (ZbroiaUA; WeaponUA) & $\begin{array}{l}\text { Wed, 16:15-16:45 } \\
\text { Sun, } 16: 15-16: 45\end{array}$ & S. Kaminskyi \\
\hline 15. & "Анатомія зради" (Anatomiia zrady; Anatomy of Treachery) & Wed, 17:00-18:00 & M. Dyzhechko \\
\hline 16. & “Будемо жити” (Budemo zhyty; We Will Live) & $\begin{array}{l}\text { Wed, } 19: 30-19: 40 \\
\text { Sat, 12:30-12:35 }\end{array}$ & \\
\hline 17. & "Точка доступу” (Tochka dostupu; Access Point) & Thu, 14:00-15:00 & I. Sampan \\
\hline 18. & “TOP UA” (TOP UA) & Thu, 17:00-18:00 & N. Hross \\
\hline 19. & $\begin{array}{l}\text { “Хіт-парад «ТОР 40»" (Khit-parad “TOP 40"; "TOP 40" Hit } \\
\text { Parade) }\end{array}$ & $\begin{array}{l}\text { Fri, 17:00-19:00 } \\
\text { Sun, 12:00-14:00 }\end{array}$ & $\begin{array}{l}\text { V. Smirnov, } \\
\text { N. Hross }\end{array}$ \\
\hline 20. & “Рейволюція” (Reivoliutsiia; Ravolution) & Fri, Sun, 21:00-21:30 & O. Bezsonov \\
\hline 21. & “Рейверський уікенд” (Reiverskyi uikend; Rave Weekend) & Sat, 19:00-21:00 & O. Bezsonov \\
\hline
\end{tabular}

Source: Own studies. 
Ukraine on the radio station's content, a subordinate body of which the company is, the broadcast surprises not only with a polyphony of ideas about the programmes content, but also with the level of skill, dedication and quality of their performance.Fulltime broadcasting of the music and information (as it determined by the employees themselves) station consists of both talk-show blocks, and of the music content, the style of which deserves more attention. In the air of "Армія FM" you can hear not only songs performed by stars of Ukrainian show business, but also foreign rock songs, as well as compositions of other styles. Approximately a half or the broadcasting is granted to national performers.

The broadcast schedule of the station consists of projects of various thematic focus, which most of all are designed in the format of dialogue of radio presenter with guests in the studio. One feature of the radio is that during the year of its work the own website had not been created. Therefore, all information about its activities can be obtained on the "Facebook" page (Військове радіо "АРМІЯ FM" на "Facebook", 2016), or by the link on the "Svoeradio" portal (Військове радіо "АРМІЯ FM" на "Svoeradio", 2016). In order to obtain a complex picture of the radio company activities we consider it expedient to provide a list of radio programmes with the indication of presenters, time and frequency of broadcasting (Tab.1).

The provided list of radio projects tellingly proves that a military radio broadcast can be polythematic, diverse, interesting and not boring at all. In addition to traditional information programmes the listeners are provided with musical, educational and informative, historical and culturological, entertaining, topical blocks that may be interesting for both service members (because some issues concerning the military service) and civilians (who live in the ATO zone and out of its bounds throughout the state). Technologies of the programmes creation is re-structured in such a way that many of them are broadcast live. Among these are the "Рота, підйом!" (Rota, pidiom! Troop, Wakey!) morning show with P. Boiko, the "Незламна" (Nezlamna; (She Is) Adamant) with M. Markevych, the "Сектор Л" (Sektor L; Sector L) with K. Potapenko and M. Muzyka, the "МінБрест" (MinBrest) with M. Brest, the "Анатомія зради" (Anatomiia zrady; Anatomy of Treachery) with М. Дижечко (M. Dyzhechko), the "Точка доступу" (Tochka dostupu; Access Point) with I. Sampan, "TOP UA", the "Хіт-парад «TOP 40»" (Khit-parad "TOP 40"; Hit Parade "TOP 40") with V. Smirnov, N. Hross (Військове радіо "АРМІЯ FM" на "Svoeradio", 2016).

Traditionally for the specialized radio station of this type the daily news block is widely presented; it consists of hourly newscast, sport review at 17:00, the "Інформаційний Дайджест за минулу добу" (Informatsiinyi Daidzhest za mynulu dobu; Information Digest for the Last Day), which is a daily ten-minute information programme broadcasted at 08:50 and at 20:00 in expanded format. Besides that news items appears in the air of radio programmes broadcasted live and becomes known to listeners from the dialogue of a presenter with a guest.

A special place in the broadcasting take short radio programmes lasting for 5-10 minutes, which in express mode, without bending a listener, convey some useful information. The thematic focus of such projects is diverse, from the education and informative "Уроки англійської" (Uroky anhliiskoi; English Lessons) programme to the problematic "Будемо жити" (Budemo zhyty; We Will Live) one; the last one is a ten-minute programme that can be heard on Wednesday at 19:30 and on Saturday at 12:30. In fact, this is a radio broadcasting of the TV programme of the same name, which goes on the air every Sunday on the "5 канал" (5 kanal; Channel 5) (Kyiv) and tells nonfictional life histories of people whose spirit has not broken by the war, and in defiance of incredible hardships they remain optimistic and believe in a bright future. An example of programmes of another type is the comic and informative "Алло! Ми шукаємо Штірліца!" (Allo! My shukaiemo Shtirlitsa! Hallo! We Are Looking for Stierlitz!) one. Funny and witty flavours of the programme perform an important function of comfort and once again prove the statement that the ridiculed problem is not so terrible. Then a joke helps to survive a stress, comforts, especially in conditions of a constant tension faced by the service members.

Evening blocks are presented by the expanded in a runtime and range of covered issues programmes, such as: "Анатомія зради" (Anatomiia zrady; Anatomy of Treachery) with M. Dyzhechko, "Спецопераціï" (Spetsoperatsii; Special Ops) with V. Shvachkin, "МінБрест" (MinBrest) with M. Brest, "Точка доступу" (Tochka dostupu; Access Point) with I. Sampan. In the air of the last one the presenter invites officials, businessmen and volunteers to conversations. For example, one of the programme's guest was A. Okuieva; she is a volunteer who after the Maidan went to the east part of Ukraine to serve in the Chechen volunteer battalion named after D. Dudaiev. One of the next programmes was focused on the story of A. Andrieiev, a former prosecutor of Luhansk region, who in 2014 resigned, witnessed the capture of the Luhansk Oblast State Administration by the separatists, and volunteered together with his colleagues to assist units of the 
Armed Forces of Ukraine (Військове радіо "АРМІЯ FM" на "Facebook", 2016).

Unique for the Ukrainian information space is a number of projects. For example, the literary "Сектор Л" (Sektor L; Sector L) programme, a slogan which the presenters K. Potapenko and M. Muzyka have formulated as "«Sector L»" - It Is Always Intellectually, invites to the conversation writers who served in the ATO zone, or directly relevant to it due to their volunteering activities or personal relations, etc. The guest of one of the programme issues was L. Yakymchuk, a journalist and a poet, the author of the "Абрикоси Донбасу" (Abrykosy Donbasu; Donbas Appricots) book. She was born and lived for a long time in the Luhansk oblast, and in 2015 published a book included in the rating of the best books about the ATO according to the Ukrainian "Forbes". In the air the poet talked about her creative work and shared plans for the future.

A noteworthy one is the "Ветерано бізнес" (Veterano biznes; Veteran Business) radio program, where L. Ostaltsev in the form of an interview tells the listeners about the success stories in the entrepreneurial field of former members of the armed conflict. Judging by the fact that the program is aired every Monday with an hour long timing for a long time, we can draw a conclusion about the sufficient number of characters, and therefore about the short success stories for the listeners. In March 2017 a guest of one of the programme issues has become a veteran of "Айдар" (Aidar) V. Khartman. After the receiving a military injuries compensation he opened two coffee bars. In the studio, he persuades that money have to be spent wisely, and it is quite possible to start an own business [Військове радіо "АРМІЯ FM" на "Facebook", 2016]. And there are a lot of such stories.

In the broadcasting schedule an entertainment segment is allocated for the "Рота, підйом!" (Rota, pidiom! Troop, Wakey!) morning show. Three-hour broadcast is composed on the principle laid by the presenter: "Without unnecessary advertising and talks! Only interesting rubrics and cool music!" (Вiйськове радіо "АРМІЯ FM" на "Facebook", 2016). In addition, guests are invited here to talk, gifts are drawn, and the listeners are informed about the most important events that occurred during the last hours. In the format of the programme of greetings and congratulations the "Привіт в АTO" (Pryvit v ATO; Hello to ATO) project is issued, where everyone who want to can send kind words to service members, who are on duty; moreover, participants in the air have an opportunity to address to their folks. The messages are received through the page on "Facebook" and "Viber". Musical blocks are presented by such programmes as "TOP UA" by N. Hross, "TOP 40" hit parade by V. Smirnov and N. Hross, and author projects of the weekend: "Рейволюція" (Reivoliutsiia; Ravolution) and "Рейверський уікенд" (Reiverskyi uikend; Rave Weekend). Both of them belong to an evening time slot of weekends. For the listeners, presenter O. Bezsonov is a kind of guide to the world of music. According to the head of the station Ya. Kholodna, "he was by a miracle transferred from the 14th brigade. There, in Mariinka, with the help of Chinese transmitter, he all by himself and voluntarily managed to set up a small radio, started to broadcast music, even made the news. Now we are expecting that he will sign a contract and will continue to serve here" (ЛаптєB, 2017). In the programmes he addresses the subjects of musical styles emergence, of inventions and events related to art, reveals the issues of music history. Here you can get to know the musical novelties from around the world, which the author carefully picks for the listeners. For example, the announcement of one of the programme is: "Today in the \#Rave_Weekend programme you will find out when the International DJ Day is celebrated, when this holiday emerged and who introduced it. And also there will be a lot of great music for a party weekend. Do not miss, it will be fun!" (Військове paдіо "АРMІЯ FM" на “Facebook", 2016).

Since the radio station has no certain site, the exchange of information with the listeners takes place mainly through the page on "Facebook". More than eight thousand of followers tracking the news of the company, so they are its supporters. Over a short period of time the radio station has become a platform uniting patriotic Ukrainian not only in the Donetsk and Luhansk regions, but also across the country. Indicative in this context is the message left by one of the users on the radio station page on the "Svoeradio". A girl under the "Jen" nickname wrote: "Say hello to my friend - his name is Illia, from Lviv soon he will go to war again. Hello from Zhenichka from Kharkiv" (Військове радіо "АРMІЯ FM" на "Svoeradio", 2016). The quote aptly illustrates not only the fact that people listen to the radio station far beyond the territories next to conflict area, but that during the war there are no citizens whose lives have not been affected by the conflict. However, we would most like to note a thirst for life, strong emotions and desire to win, which is particularly strongly felt in the listeners messages; just look at these messages: "Our guys definitely will win. We believe in them!" (User "Olha"), or "Finally a normal radio appeared" (user "Balabina") (Військове радіо "APMIЯ FM" на "Svoeradio", 2016). Such friendly attitude of the listeners is a result of understanding by the administration and management of all responsibility 
that falls on the shoulders of members of the "first radio in Ukraine made by the military" (Військове радіо "АРМІЯ FM" на "Svoeradio", 2016). Thus the founder of the radio station Ya. Kholodna notes:"I will never allow to read regulations or conduct a drill training in the broadcasting of our radio station from morning till night. Our listeners, combatants, they are first and foremost are people and need the appropriate attitude. They have enough "military" on locations, but in some way they have to rest from this, to relax, to get some interesting information" (Військове радіо “АРМІЯ FM" на “Facebook", 2016).

\section{Summary}

There is much concern about the problem of information support of member service who are in the ATO zone and of local citizens since the beginning of the conflict. And if the owners of private radio stations master the broadcasting time at their own discretion and often immolates such programmes, then the state broadcasters become flagships of radio signal broadcasting on the east of Ukraine. The information vacuum about which Ukrainian soldiers complain, can be more deafening than salvos of military weaponry, because as victims of the hostile propaganda fall not only civilians, but service members too, who are on the frontline. The realia of the military situation development, as well as the media focus on the information support of this topic creates new forms of radio broadcasting. We can see trends of the development of complete specialized military radio stations, which focus on a narrow but loyal audience that is co-thinkers. In the future, such channels can become a gathering place for the listeners united by common problems, by life stories, which can be understood and heard be people who were caught in similar life situations. And when the long-awaited peace will come to Ukrainian land, these radio stations will be the medium which unite around them non-indifferent patriotic public.

\section{References}

Garcia Raya M.E., 2003, Strategy in Internal Armed Conflicts, Television \& New Media, 4, 71-84.

Reljiic D., 2004, The News Media and the Transformation of Ethnopolitucal Conflicts, Berghof Research Center for Constructive Conflict Management, Berghof.

Буроменський М., 2016, Журналістика в умовах конфрлікmy: передовий досвід та рекомендачії: Посібник рекомендачій для прачівників 3MI, Компанія BAITE, Київ.

Військове радіо "АРМІЯ FM" на "Facebook", 2016, https:// www.facebook.com/armyuaFM/ [01.02.2017].
Військове радіо "АРМІЯ FM" на "Svoeradio", 2016, http://svoeradio.com/listen/arm-ya-FM-retranslation [01.02.2016].

Гиріна Т., 2016, Соціальна роль радіомовлення в період військового конфлікту на Сході України: сучасний стан та перспективи трансформації, Держава та регіони. Серія: Сочіальні комунікації, 4, 45-51.

Кобра Г, 2009, Сучасні збройні конфлікти у виданнях "Rzeczpospolita”, та "Gazeta Wyborcza”, Вісник Львівського університету. Серія журналістика, 32, 252-260.

Кондратюк М., 2013, Інформаційна війна та роль мас-медіа в міжнародних конфліктах, Вісник Харківської державної академії культури, 41, 108-113.

Лаптєв Ю., 2017, Яна Холодна: “Ми змогли позбутися "совка", і че насправді надихає", http://m.tyzhden.ua/ Society/186606 [01.03.2017].

На окупований Крим почали мовлення дві українські радіостанції, 2017, http://espreso.tv/news/2017/02/09/ na_okupovanyy_krymu_pochaly_movlennya_dvi_ ukrayinski_radiostanciyi [09.02.2017].

Пашніна О., 2009, Особливості висвітлення військових конфліктів телемережею CNN Науковий вісник Волинського національного університету імені Лесі Українки, Науковий вісник Волинського національного університету імені Лесі Українки, 25, 72-76.

Путькалець Л., 2015, Роль державних телерадіокомпаній у формуванні інформаційного простору регіону, Телета радіожурналістика, 14, 82-86.

Родик Г., 2012, Роль засобів масової комунікації в міжетнічних конфліктах, Панорама політологічних студій: Нaуковий вісник Рівненського державного гуманітарного університету, 8, 41-46.

США проспонсируют создание в Украине военного радио, 2015, http://korrespondent.net/ukraine/3604620-sshaprosponsyruuit-sozdanye-v-ukrayne-voennoho-radyo [01.02.2017]. 